\title{
Fragrant Rubber Sole with New Formulation Employing EVA Crump
}

\author{
Omprakash H. Nautiyal
}

Alert India Pvt. Ltd., C-21, SMA Industrial Area, New Delhi 110033, India

\begin{abstract}
The invention provides improvement over the entire physical properties of rubber soles like tensile strength, modulus strength, shore A. Oil 205 and 541 have a very good lubricating effect on their microcellular structure, breakability and resilience. An aroma was introduced to mask the rubber smell and the shore A was further investigated employing the naphthenic oil that was added in higher and lower dosages in the formulations. The cost factor of the soles was bit high that compare to other oils like 205 and 541. Their physical evaluation at FDDI was found to be compatible from customers' point of view. Tensile strength was from $104-146 \mathrm{Kg} / \mathrm{cm} 2$ and the elongation was $680-850 \%$. Hardness shore A was from 33-68 and volume loss was from $190-265 \%$.
\end{abstract}

Keywords Rubber sole, naphthenic oil, oil 205, oil 541, Aroma

\section{Introduction}

We aimed at manufacturing the rubber soles with the use of SBR, RMA and PBR and making it rubber odour free employing an aroma of vanilla base. Our investigation was successful from the compatibility point of view that the hardness, specific gravity, tensile strength $\mathrm{Kg} / \mathrm{cm}^{2}$, modulus $\mathrm{Kg} / \mathrm{cm}^{2}$, elongation at break $\%$, abrasion resistance and spilt tear strength. All these physical parameters were good from market business.

The broadest categories of latex polymers are natural rubber latexes and synthetic latexes. Natural rubber latexes include high ammonia latex, low ammonia latex and graft polymer latex.

In the Hevea Brasiliensis (rubber) tree, the latex is stabilized by protein. Once it is tapped from the tree, the natural protein is susceptible to attack by bacteria upon exposure to oxygen in the atmosphere. This degradation of the protein and subsequent coagulation of the latex renders the "field latex" putrid and rancid. ${ }^{1-15}$

Field latex contains approximately $30 \%$ rubber, $5 \%$ of natural protein, fatty acids and impurities, and $65 \%$ water. In this state, it would not be economically efficient for industrial use or for transportation. Centrifuging is the major means by which the solids concentration is increased from $30 \%$ to $60 \%$ and higher. Creaming, another method of layer separation, is also used, but to a lesser extent.

High ammonia latex is the result of increased stabilization

* Corresponding author:

opnautiyalus@yahoo.com (Omprakash H. Nautiyal)

Published online at http://journal.sapub.org/ajps

Copyright (C) 2012 Scientific \& Academic Publishing. All Rights Reserved by the addition of further ammonia following concentration of the latex. The additional ammonia raises the $\mathrm{pH}$ of the latex to approximately 11 to 12 .

Low ammonia latex was developed because manufacturers objected to the noxious ammonia odor in their factories. A popular method to minimize the amount of ammonia in latex is to replace part of it with a combination of zinc oxide and the accelerator tetramethythiuramdisulfide (METHYL TUADS® (TMTD)).

The $\mathrm{pH}$ of this latex is approximately 10 to 11 . Graft polymer latex 1 is a copolymer of natural rubber latex (polyisoprene) and polymethylmethacrylate. It is used primarily in the adhesives industry. The poly methylmethacrylate contributes specific adhesion as well as high modulus (immediate strength) to the natural latex.

Due to its superior physical properties, which are unmatched by any synthetic latex, the applications of natural latex are numerous. They include medical devices like condoms, surgeon and examination gloves, lineman gloves, thread used in clothing and undergarments, balloons, molded goods and novelties.

However, the recent awareness that the natural protein stabilizer can cause allergic reactions has limited its use. Because of this consideration, natural rubber latex products have been replaced to some degree by synthetic rubber products, especially in unsupported examination gloves.

Synthetic rubber latexes include styrene butadiene rubber (SBR), acrylonitrile butadiene rubber (NBR), polychloroprene rubber (CR), butyl rubber (IIR), and synthetic polyisoprene rubber (IR). There are other specialized synthetic rubber latexes, such as HYPALON ${ }^{\circledR}$ latex and EPDM latex, but they will not be discussed because of their limited application. 
SBR latex finds its main applications in foam, paper and coatings. While the carboxylated versions of SBR (XSBR) are supplanting conventional SBR latex because of their faster cure rate, the resilience, processing ease and economy of SBR latex keeps it a viable commodity. SBR is very compatible with natural rubber latex, and is frequently blended with it for use in the carpet backing and Rug underlay industry. The ratio of rigid styrene to flexible butadiene can be adjusted to alter the physical properties of the latex.

NBR latex was for many years limited to solvent- and grease-resistant applications like paper coatings and non-woven gasketing materials. Due to the allergy concerns mentioned above, carboxylated NBR or XNBR latex is today the most popular synthetic latex alternative for unsupported examination gloves. ${ }^{1-15}$

Poly chloroprene (NEOPRENE) latex is the second most popular synthetic alternative to natural latex for unsupported examination gloves, and is increasingly used in household gloves. Weather balloons and medical breather bags are made from poly chloroprene latex because of its good weather and aging resistance. It is also used in many types of coatings and adhesives.

Poly isoprene latex, having been experimental for many years, is gaining popularity in the glove dipping industry.

Butyl latex finds its greatest use in chemical-resistant applications, especially in supported chemical handling gloves and adhesives.

\subsection{Stabilizers}

Ionic stabilization cannot be discussed without an understanding of coagulation. The tiny droplets of rubber (the oil phase) that are suspended in a water medium (water phase) are kept separated by ionic charges in most cases.

When the surface of the droplets is negatively charged, for instance, they will never coalesce, because "like charges" repel each other. When the ionic charges are intact and the droplets remain suspended and separated from each other, the latex is stabilized. When the ionic equilibrium is upset and the droplets coalesce or amalgamate, the latex is coagulated. Coagulation is not reversible. ${ }^{1-15}$

Latexes can be stabilized anionically, as described above, cationically, by positive charges, or even nonionically. Anionic latexes are predominant in the latex industry. When an anionic stabilizer like DARVAN WAQ is dissolved in water, the negatively charged anions are of greater magnitude than the positively charged cations, and surround the rubber droplets so that they repel each other. Cationically stabilized latex would be just the opposite, but is no longer common.

Latexes can also be protected physically with nonionic stabilizers that are normally long chain alcohols. They simply form physical barriers between the droplets of rubber.

There is a fourth type of latex stabilizer called amphoteric. Its positive and negative ionic charges are of equal strength. It is an auxiliary rather than a primary stabilizer, reinforcing the charge that already exists on the droplet, whether positive or negative.

It is important to remember that being able to produce coagulation on demand is an essential processing property. Without it, no latex product could be manufactured. The degree of stability in latex must therefore be appropriate to withstand the rigors of mechanical and chemical processing, but not so as to prevent coagulation from taking place at a time and under conditions of the compounder's choosing.

During storage, mixing, and processing, latex stabilization is challenged by both physical and chemical outside forces: time, temperature, phase separation, $\mathrm{pH}$ drift, shear in mixing, pumping and coating techniques, addition of incompatible materials like some electrolytes, particles of a substantially different diameter, and dissimilar stabilization systems.

Natural rubber latex is stabilized by natural protein and the soaps formed when the added ammonia combines with the fatty acids in the latex. When the high ammonia content of natural rubber latex is undesirable, low ammonia latex can be substituted, in which part of the ammonia is replaced by an auxiliary stabilizer such as a combination of zinc oxide and tetramethyl thiuram disulfide (METHYL TUADS (TMTD)). ${ }^{16-21}$

Synthetic latex is primarily stabilized with anionic soaps of the fatty acid and rosin acid type. These are added during the polymerization stage of manufacture to protect the newly formed latex rubber particles against the shear forces of mixing and processing. This is a major characteristic of synthetic latexes versus natural rubber latexes: they are highly stabilized.

In the coatings industry, the migration of water-soluble soaps to the film surface makes it difficult to overcoat or to coat successive layers of synthetic latex. The successive latex films do not "knit" together. The interlayer of stabilizer prevents the latex from becoming an amalgamated unit. The layers of latex film can frequently be peeled away from each other. This same migration of soap also prevents good surface bonding in adhesives.

In the dipped goods industry, it is often necessary to use an excess of external coagulants in order to overcome the effect of the synthetic latex stabilizers and build a suitable film thickness. In so doing, another problem is created, in that leaching times must be extended to remove the water-soluble stabilizer and additional coagulant.

Frequently, additional stabilizers are added to both natural and synthetic latex before compounding. An example is sodium lauryl sulfate. It is added when severe plant processing is anticipated: shear mixing, pumping, fabric impregnation. It is sometimes added when the holding or dipping tanks are large and the latex compound will remain in them for a long time, or to latex that will be pre vulcanized, in order to protect against the increased temperature. Usually, the need for additional stabilizers to control the mixing of special ingredients into the latex has to be resolved in the laboratory. 
Sulfated methyl oleate (DARVAN SMO) is a special stabilizer. It not only reinforces the ionic charges protecting the droplets of rubber in the latex, but has come to be recognized for its more specialized purpose use as a film conditioner. $16-21$

\subsection{Cross linkers}

Vulcanization creates a "memory" in a rubber polymer. After the stress or strain of distortion or stretching is removed, the polymer returns to its original shape. This is what distinguishes a rubber from a thermoplastic. It is accomplished by connecting the molecular chains of the polymer to each other.

Cross linkers are the chemicals that connect these molecular chains. Since the chains are linked, a force is required to pull them apart. The strength of this force is a measure of the efficiency and number of connecters or cross links. The force required to stretch a cross linked polymer to a specified elongation is called a modulus. The force required to completely separate a cross linked polymer is called the tensile strength. ${ }^{1-15}$

Sulfur is the primary cross linker for most natural and synthetic rubbers. In poly chloroprene (NEOPRENE), however, sulfur is the secondary cross linker.

Zinc chloride (zinc from zinc oxide and chlorine from the polymer) constitutes the primary cross linker.

There is other cross linking or vulcanizing systems. Carboxylated polymers are cross linked with metal oxides. 4 in peroxide curing 5; free radicals are formed on the carbon chains by the excitation of decomposing peroxides. The free radicals formed connect with each other to create carbon to carbon cross links. ${ }^{16-21}$

\subsection{Activators}

Sulfur alone will vulcanize (cure or crosslink) rubber latexes. However, at elevated temperatures, the process will theoretically take days, during which time oxidation would destroy the polymer before sufficient cross linking could take place. Zinc oxide activates the cross linking action of the sulfur. A sulfur/zinc oxide cure of rubber latex can take place in a matter of hours at elevated temperatures, subject to the degrading effects of oxidation.

\subsection{Accelerators}

Accelerators have made latex a viable industry, and have made latex products readily available worldwide by reducing their cure time to minutes. Most accelerators for sulfur cures are nitrogen-bearing. They fall into classes called dithiocarbamates (BUTYL ZIMATE®, SETSIT thiurams (METHYL TUADS (TMTD), SULFADS ${ }^{\circledR}$ (DPTT)), sulfonamides (MORFAX ${ }^{\circledR}$ ), and thiazoles (CAPTAX® $($ MBT), ZETAX ${ }^{\circledR}$ ). The xanthates (PROPYL ZITHATE ${ }^{\circledR}$ ) are an exception because they do not contain nitrogen. Guanidines (VANAX ${ }^{\circledR}$ DPG and VANAX DOTG) and thioureas (THIATE® U and THIATE EF) accelerate the zinc Chloride cross linking of poly chloroprenes. Accelerators for metal oxide cross linking in a carboxylic polymer are not necessary unless a dual system of metal oxide and sulfur vulcanization is required for optimum properties. ${ }^{16-21}$

The combination of cross linkers, activators and accelerators not only determines the rate of cure, as mentioned, but the state of cure. It is the responsibility of the latex chemist to optimize the desired physical properties of the finished article by manipulating the levels of the cross linker, the activator, and the accelerator. In the case of natural rubber latex, vulcanization can take place in the colloidal state; rapid cures may therefore not always be desirable.

The more preferred organic polymers employable in this study are the conventional vulcanisable unsaturated rubber polymers used to prepare vulcanisable rubber compounds. Illustrative of such vulcanisable rubber polymers are natural rubber and synthetic rubber polymers as disclosed, e.g. in The Elastomeric Manual (1972 Edition) published by International Institute of Synthetic Rubber Producer, Inc., such as styrene-butadiene rubber polymers, butadiene rubber polymers, ethylene-propylene rubber terpolymers, chloroprene rubber polymers, nitrile rubber polymers, bromo- and chloro- butyl rubber polymers, poly isoprene rubber polymers, and the like. Especially preferred are the conventional sulphur vulcanisable rubber polymers such as natural rubber, styrene-butadiene rubber polymers, butadiene rubber polymers, and poly isoprene rubber polymers. ${ }^{16-21}$

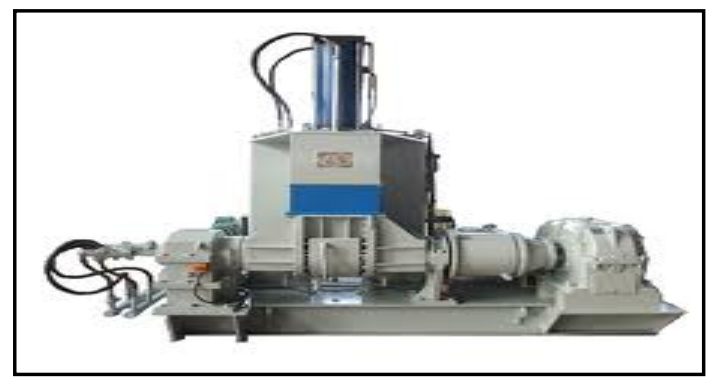

Figure 1. Rubber Kneading Machine

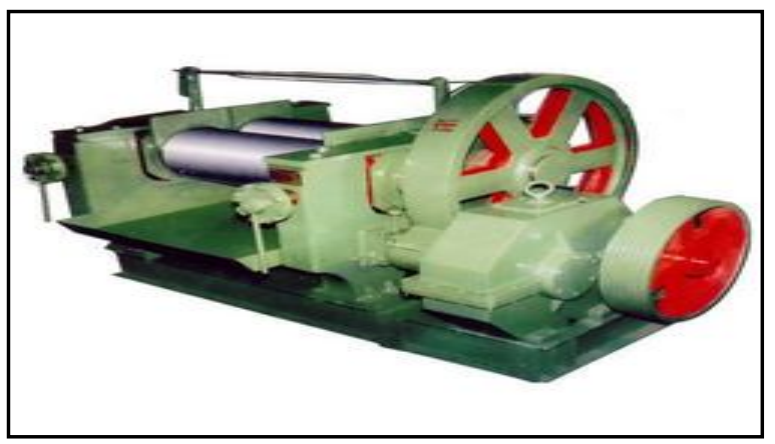

Figure 2. Rubber Rolling/Milling Machine

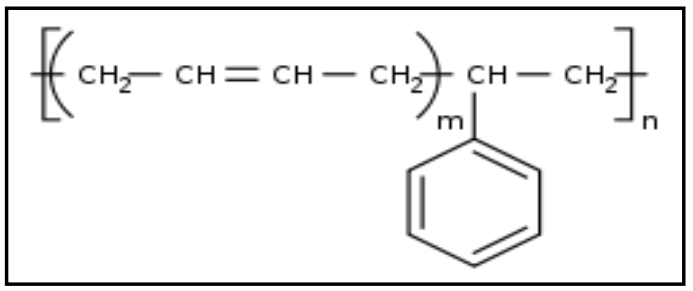

Figure 3. Styrene-butadiene rubbers 



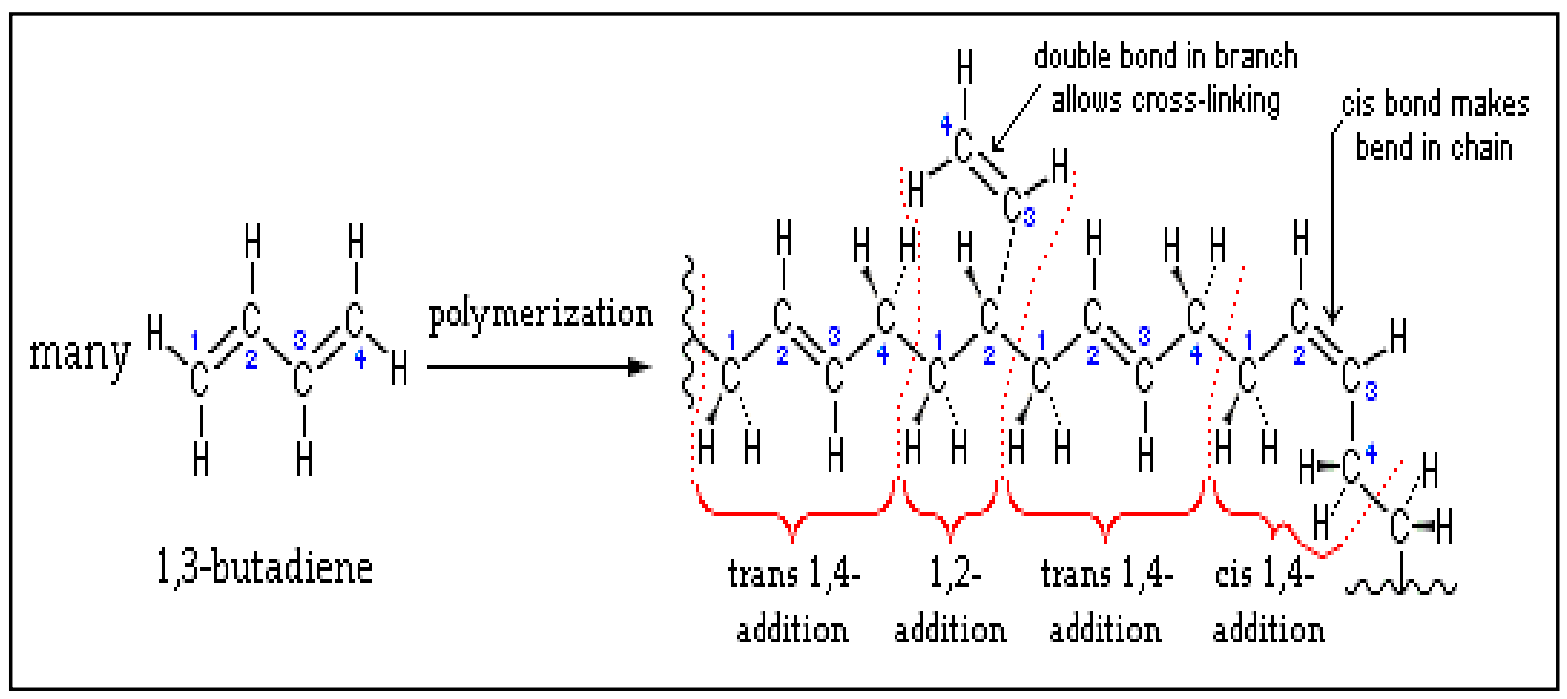

Figure 4. Poly butadiene rubbers

Some rubber compounds, such as those used in shoe soles, rubber bands, etc, need to be transparent or translucent. Unfortunately, ordinary zinc oxide by itself impairs transparency and/or translucency. For example, French process zinc oxide will render a cured rubber compound white and non-transparent at concentrations even as low as $1.5 \mathrm{phr}$ (parts per hundred parts of rubber). Zinc carbonate may be used instead of zinc oxide in rubber compounding at somewhat higher concentrations. However, at $5 \mathrm{phr}$, good commercial zinc carbonate still does not render the rubber compound totally non-transparent. ${ }^{16-21}$

\section{Materials and methods}

The kneader machine and roll mill was locally purchased. The manual operating moulding machine was imported from China. The ingredients SBR 1502, RMA IX, PBR, ZnO, Stearic acid, VN3 silica, Oil 205, Vulcanit G(PVI) (FB), HS/LG (TMQ), PEG \#4000, Carbon black, EVA crump and naphthenic oil were imported from China and few were purchased at India. Master batch raw materials, MBT, MBTS, TMTD, Sulphur and curing agent were resourced from India.

\subsection{Kneading of Rubber}

It was of $200 \mathrm{Kg}$ capacity and each time, $150 \mathrm{Kg}$ of rubber was admixed with the ingredient mentioned earlier and was kneaded for $1 \mathrm{~h}$ to $2 \mathrm{~h}$ until the ingredients get mixed well.

\subsection{Mill roller}

The kneaded rubber was then introduced to the roll press for half an hour and then the master batch was allowed to admix thoroughly. After, almost half hour sulphur as weighed quantity was put over the flattened rubber. To make it best vulcanized calcium carbonate was powdered over it and allowed get properly distributed. After an hour then it was allowed to get cured for overnight. After $24 \mathrm{~h}$ it was transferred to manufacturing area. The rubber sheet was cut into pieces weighing 250-300 g, it was introduced to the moulds, and the moulds were clipped and operated for the casting at $180{ }^{\circ} \mathrm{C}$. To avoid the burning of the soles $60-75$ seconds of each hard pressing round were allowed to repeat for five to six times. Once that was done then the moulds were pulled out and de moulded while spraying the silicon releasing agent to free it from the casting. The casted rubber soles then taken for quality control testing.

The testing covers hardness Shore A, specific gravity, tensile strength $\mathrm{Kg} / \mathrm{cm}^{2}$, modulus at $300 \% \mathrm{Kg} / \mathrm{cm}^{2}$, elongation at break \%; volume loss $\%$ and split tear strength $\mathrm{Kg} / \mathrm{cm}^{2}$. ${ }^{16-21}$

\section{Results and discussion}

The addition of naphthenic oil has great influence on all the properties of the soles. At $8 \mathrm{Kg}$ phr it yielded the soles with 68 and 33 hardness shore $\mathrm{A}$, at $5 \mathrm{Kg}$ phr the soles were with 45 and $58 \mathrm{Kg}$ shore A. At $10 \mathrm{Kg} \mathrm{phr}$ it gave the soles of 55 and 62 shore A. But when the dose was reduced to $1.2 \mathrm{Kg}$ phr then the results were comparatively good with than that of high quantity. Use of EVA crumps helped in increasing the tensile strength and modulus $\%$ of 108 and $19.42 \mathrm{Kg} / \mathrm{cm}^{2}$ and 100 and $37 \mathrm{Kg} / \mathrm{cm}^{2}$. In some cases the elongation test was low using EVA crumps almost of the value of $475 \%$. High quantity of naphthenic oil along with oil 205 resulted in the soles with very poor shore A. The shore A was analysed to be 38 , whereas when the quantity of naphthenic oil was reduced and oil 205 was kept out of the formulation then the shore A of the sole rose to 58. It was revealed that high content of naphthenic oil was providing too much of lubrication to the formula and the shore A was getting poor. MBT, MBTS, TMTD and sulphur were kept consistent along with sulphur. In one of the formulation when stearic acid was not include then it was found that the rubber soles were found to broken within 3-4 days. $\mathrm{ZnO}$ has helped in establishing a balanced network of isoprene unit that gave a firm microcellular structure and thus yielded the soles with firm heals. 
$21-25$

SBR can be produced by two basically different processes: from solution (S-SBR) or as emulsion (E-SBR). In the first instance the reaction is ionic polymerization, in the emulsion polymerization case the reaction is via free radical polymerization. In that process; Low pressure reaction vessels are required and usually charged with styrene and butadiene, the two monomers, a free radical generator and a chain transfer agent such as an alkyl mercaptan and water. Mercaptans controls molecular weight and high viscosity product from forming. The anionic polymerization process is initiated by alkyl lithium and water not involved. High styrene content rubbers are harder but less rubbery. ${ }^{26-29}$

Natural rubber (RMA 1X), also called India Rubber or caoutchouc, is an elastomeric (an elastic hydrocarbon polymer) that was originally derived from latex, a milky colloid produced by some plants. The plants would be 'tapped', that is, an incision made into the bark of the tree and the sticky, milk colored latex sap collected and refined into a usable rubber. The purified form of natural rubber is the chemical poly isoprene, which can also be produced synthetically. Natural rubber is used extensively in many applications and products, as is synthetic rubber. It is normally very stretchy and flexible and extremely waterproof.

Latex is a natural polymer of isoprene (most often cis-1, 4-polyisoprene) - with a molecular weight of 100,000 to $1,000,000$. Typically, a small percentage (up to $5 \%$ of dry mass) of other materials, such as proteins, fatty acids, resins and inorganic materials (salts) are found in natural rubber. Poly isoprene is also created synthetically, producing what is sometimes referred to as "synthetic natural rubber".

Poly butadiene is a synthetic rubber that is a polymer formed from the polymerization process of the monomer 1 , 3-butadiene. It has a high resistance to wear and is used especially in the manufacture of tires, which consumes about
$70 \%$ of the production. Another $25 \%$ is used as an additive to improve the mechanical strength of plastics such as polystyrene and acrylonitrile butadiene styrene (ABS). It is also used to manufacture golf balls, various elastic objects and to coat or encapsulate electronic assemblies, offering extremely high electrical resistivity. It exhibits a recovery of $80 \%$ after stress is applied, a value only exceeded by elastin and resilin.

The butadiene molecule can be polymerized in three different ways, giving rise to three isomers called cis, Trans and vinyl. The properties of polybutadiene are different depending on the proportion of these isomers. For example, polybutadiene called "high cis" has a high elasticity and is very popular while the so-called "high trans" is a plastic crystal without any useful application. ${ }^{26-30}$

The polymers are linear or branched. The conjugated dienes suitable are those which ordinarily contain 4 to about 12 carbon atoms per molecule with those containing 4 to about 8 carbon atoms being preferred and are exemplified by 1,3-butadiene, isoprene, piperylene, 2,3-dimethyl-1, 3- butadiene, 3-butyl-1,3-octadiene, 2-phenyl-1,3-butadiene, and the like, and mixtures thereof. The mono vinylarenes suitable are those which ordinarily contain 8 to about 16 carbon atoms per molecule and are exemplified by styrene, alpha-methyl styrene, 3-methyl styrene, 4-n-propyl styrene, 4-p-tolyl styrene, 1-vinyl naphthalene, and the like, and mixtures thereof. The reinforcing fillers suitable for use in this invention include any type of silica-containing material which is considered to have reinforcing properties. These are often described as siliceous fillers and refer to fillers which are rubber compatible or can be worked into rubber mixtures, said fillers consisting of silicates or silica or contain silicas or silica and/or contain chemically bound silicates (or silica) in the widest sense including mixtures of two or more siliceous fillers. ${ }^{26-29}$

Table 1. Rubber formulations with oil grades

\begin{tabular}{|c|c|c|c|c|c|}
\hline Sl. No. & Ingredients & Black With Oil205 & Black With Oil 541 & Brown With Oil 205 & Brown With Oil 541 \\
\hline 1 & SBR 1502 & 13.825 & 13.825 & 9.855 & 9.855 \\
\hline 2 & RMA 1X & 10.753 & 10.753 & 14.782 & 14.782 \\
\hline 3 & PBR & 3.072 & 3.072 & 8.212 & 8.212 \\
\hline 4 & ZnO & 1.536 & 1.536 & 1.825 & 1.825 \\
\hline 5 & ST. ACID & 0.845 & 0.845 & 1.004 & 1.004 \\
\hline 6 & VN3 SILICA & 9.677 & 9.677 & 15.000 & 15.000 \\
\hline 7 & Oil 205 Kg & 4.608 & 0.000 & 7.000 & 0.000 \\
\hline 8 & MC WAX & 0.307 & 0.307 & 0.365 & 0.365 \\
\hline 9 & HS/ LG (TMQ) & 0.154 & 0.154 & 0.183 & 0.183 \\
\hline 10 & PEG \#4000 & 0.104 & 0.104 & 0.123 & 0.123 \\
\hline 11 & CARBN BLACK (N 220) & 5.530 & 5.530 & 0.000 & 0.000 \\
\hline 12 & EVA Crump & 9.670 & 9.670 & 0.000 & 0.000 \\
\hline 13 & Napthenic Oil (541) & 0.000 & 2.850 & 0.000 & 5.000 \\
\hline 14 & Aroma (Perfume) & 0.030 & 0.030 & 0.030 & 0.030 \\
\hline 15 & Pigment (Carbon Black) & & & 0.030 & 0.030 \\
\hline 16 & Pigment (Red Oxide) & & & 0.042 & 0.042 \\
\hline MASTER BATCH WT. (Kg)/ Cost & 60.11 & 58.353 & 58.45 & 56.451 \\
\hline \multicolumn{2}{|r|}{} & MB Cost / Kg & MB Cost / Kg & MB Cost / Kg & MB Cost/ Kg \\
\hline 15 & MBTS & 0.138 & 0.138 & 0.328 & 0.328 \\
\hline 16 & TMTD & 0.354 & 0.354 & 0.840 & 0.840 \\
\hline 17 & & 0.039 & 0.091 & 0.091 \\
\hline
\end{tabular}




\begin{tabular}{|c|c|c|c|c|c|}
\hline 18 & SULPHUR & 0.645 & 0.645 & 1.537 & 1.537 \\
\hline 19 & Vulcanit -G(PVI)(FB) & 0.024 & 0.024 & 1.537 & 1.537 \\
\hline \multicolumn{2}{|c|}{ CURING AGENT WT. (Kg) } & 1.200 & 4.333 & 4.333 & \\
\hline \hline \multicolumn{2}{|c|}{ TOTAL WT. (Kg) } & 61.311 & 62.686 & 62.784 & 56.451 \\
\hline
\end{tabular}

Table 2. Rubber formulations with physical properties of the soles

\begin{tabular}{|c|c|c|c|c|c|c|c|c|c|c|}
\hline Sl. No. & Ingredients & $\mathrm{A}$ & B & $\mathrm{C}$ & $\begin{array}{l}\text { R \& D } \\
\text { No. } 01\end{array}$ & $\begin{array}{l}\text { R \& D } \\
\text { No. } 02\end{array}$ & $\begin{array}{l}\mathrm{R} \& \mathrm{D} \\
\text { No. } 03\end{array}$ & $\begin{array}{l}\text { R \& D } \\
\text { No. } 04\end{array}$ & $\begin{array}{l}\mathrm{R} \& \mathrm{D} \\
\text { No. } 05\end{array}$ & $\begin{array}{l}\text { R \& D } \\
\text { No. } 06\end{array}$ \\
\hline 1 & SBR 1502 & 50.000 & 50.000 & 50.000 & 50.000 & 50.000 & 50.000 & 50.000 & 50.000 & 50.000 \\
\hline 2 & RMA 1X & 38.889 & 38.889 & 38.889 & 38.889 & 38.889 & 38.889 & 38.889 & 38.889 & 38.889 \\
\hline 3 & PBR & 11.111 & 11.111 & 11.111 & 11.111 & 11.111 & 11.111 & 11.111 & 11.111 & 11.111 \\
\hline 4 & $\mathrm{ZnO}$ & 5.556 & 5.556 & 5.556 & 5.556 & 5.556 & 5.556 & 5.556 & 5.556 & 5.556 \\
\hline 5 & ST. ACID & 3.056 & 3.056 & 3.056 & 3.056 & 3.056 & 3.056 & 3.056 & 3.056 & 3.056 \\
\hline 6 & VN3 SILICA & 38.889 & 35.000 & 35.000 & 35.000 & 35.000 & 35.000 & 35.000 & 35.000 & 35.000 \\
\hline 7 & Oil $205 \mathrm{Kg}$ & 16.667 & 16.667 & 16.667 & 16.667 & 8.333 & 8.333 & 8.333 & 12.083 & 0 \\
\hline 8 & MC WAX & 1.111 & 1.111 & 1.111 & 1.111 & 1.111 & 1.111 & 1.111 & 1.111 & 1.111 \\
\hline 9 & Vulcanit -G(PVI)(FB) & 0.083 & 0.083 & 0.083 & 0.083 & 0.083 & 0.083 & 0.083 & 0.083 & 0.083 \\
\hline 10 & HS/ LG (TMQ) & 0.556 & 0.556 & 0.556 & 0.556 & 0.556 & 0.556 & 0.556 & 0.556 & 0.556 \\
\hline 11 & PEG \#4000 & 0.375 & 0.375 & 0.375 & 0.375 & 0.375 & 0.375 & 0.375 & 0.375 & 0.375 \\
\hline 12 & CARBON BLACK & 8.330 & 20.000 & 20.000 & 20.000 & 20.000 & 20.000 & 20.000 & 20.000 & 20.000 \\
\hline 13 & EVA Crump & 0.000 & 0.000 & 35.000 & 0.000 & 0.000 & 0.000 & 35.000 & 35.000 & 35.000 \\
\hline 14 & Napthenic Oil & 0.000 & 0.000 & 0.000 & 8.000 & 8.000 & 5.000 & 5.000 & 1.250 & 10.000 \\
\hline 15 & Aroma (Perfume) & 0.000 & 0.000 & 0.000 & 7.980 & 0.300 & 0.300 & 0.300 & 0.300 & 0.300 \\
\hline \multicolumn{2}{|c|}{ MASTER BATCH WT. (Kg) } & 174.623 & 182.404 & 217.404 & 198.384 & 182.370 & 179.370 & 214.370 & 214.370 & 211.037 \\
\hline 14 & MBT & 0.500 & 0.500 & 0.500 & 0.500 & 0.500 & 0.500 & 0.500 & 0.500 & 0.500 \\
\hline 15 & MBTS & 1.278 & 1.278 & 1.278 & 1.278 & 1.278 & 1.278 & 1.278 & 1.278 & 1.278 \\
\hline 16 & TMTD & 0.139 & 0.139 & 0.139 & 0.139 & 0.139 & 0.139 & 0.139 & 0.139 & 0.139 \\
\hline 17 & SULPHUR & 2.333 & 2.333 & 2.333 & 2.333 & 2.333 & 2.333 & 2.333 & 2.333 & 2.333 \\
\hline \multicolumn{2}{|c|}{ CURING AGENT WT. (Kg) } & 4.250 & 4.250 & 4.250 & 4.250 & 4.250 & 4.250 & 4.250 & 4.250 & 4.250 \\
\hline & & & & & & & & & & \\
\hline \multicolumn{2}{|c|}{ TOTAL WT. (Kg) } & 178.873 & 186.654 & 221.654 & 202.634 & 186.620 & 183.620 & 218.620 & 218.620 & 215.287 \\
\hline \multicolumn{2}{|c|}{ Laboratory Test Report 02/07/2011 } & & & & \multicolumn{2}{|c|}{$\begin{array}{l}\text { Laboratory Test Re- } \\
\text { port } 22 / 07 / 2011\end{array}$} & \multicolumn{2}{|c|}{$\begin{array}{l}\text { Laboratory Test Re- } \\
\text { port } 03 / 08 / 2011\end{array}$} & \multicolumn{2}{|c|}{$\begin{array}{l}\text { Laboratory Test Re- } \\
\text { port } 10 / 08 / 2011\end{array}$} \\
\hline 1 & Hardness (Shore A) & 52 & 58 & 68 & 33 & 38 & 45 & 58 & 55 & 62 \\
\hline 2 & Specific Gravity & 1.02 & 1.03 & 1.03 & 1.02 & 1.02 & 1.00 & 0.99 & 1.01 & 1.02 \\
\hline 3 & $\begin{array}{l}\text { Tensile Strength } \\
(\mathrm{Kg} / \mathrm{cm} 2)\end{array}$ & 146 & 128 & 108 & 110 & 115 & 142 & 100 & 106 & 104 \\
\hline 4 & $\begin{array}{l}\text { Modulus at } 300 \% \\
(\mathrm{Kg} / \mathrm{cm} 2)\end{array}$ & 26.3 & 21.41 & 19.42 & $* * *$ & 20.47 & 39 & 37 & 38 & 35 \\
\hline 5 & Elongation at Break \% & 815 & 610 & 475 & 820 & 850 & 785 & 690 & 680 & 850 \\
\hline 6 & $\begin{array}{c}\text { Abrasion Resistance } \\
\text { (Volume loss ) \% }\end{array}$ & 250 & 265 & 280 & 260 & 210 & 140 & 190 & 180 & 190 \\
\hline 7 & $\begin{array}{c}\text { Split Tear Strength } \\
(\mathrm{Kg} / \mathrm{cm})\end{array}$ & $* * *$ & $* * *$ & $* * *$ & $* * *$ & $* * *$ & $* * *$ & $* * *$ & & \\
\hline
\end{tabular}

Table 3. Cost evaluations of rubber formulations

\begin{tabular}{|c|c|c|c|c|c|c|c|c|c|c|}
\hline $\begin{array}{c}\text { Sl. } \\
\text { No. }\end{array}$ & Ingredients & $\begin{array}{c}\text { Rate/ } \\
\mathrm{Kg}\end{array}$ & $\mathrm{A}$ & Cost & $\mathrm{B}$ & Cost & $\mathrm{C}$ & Cost & $\begin{array}{c}\mathrm{R} \& \mathrm{D} \\
\text { No. 01 }\end{array}$ & Cost \\
\hline 1 & SBR 1502 & 222 & 50.000 & 11100.00 & 50.000 & 11100.00 & 50.000 & 11100.00 & 50.000 & 11100.00 \\
\hline 2 & RMA 1X & 276 & 38.889 & 10733.36 & 38.889 & 10733.36 & 38.889 & 10733.36 & 38.889 & 10733.36 \\
\hline 3 & PBR & 239 & 11.111 & 2655.53 & 11.111 & 2655.53 & 11.111 & 2655.53 & 11.111 & 2655.53 \\
\hline 4 & ZnO & 115 & 5.556 & 638.94 & 5.556 & 638.94 & 5.556 & 638.94 & 5.556 & 638.94 \\
\hline 5 & ST. ACID & 70 & 3.056 & 213.92 & 3.056 & 213.92 & 3.056 & 213.92 & 3.056 & 213.92 \\
\hline 6 & VN3 SILICA & 56 & 38.889 & 2177.78 & 35.000 & 1960.00 & 35.000 & 1960.00 & 35.000 & 1960.00 \\
\hline 7 & Oil 205 Kg & 69 & 16.667 & 1150.02 & 16.667 & 1150.02 & 16.667 & 1150.02 & 16.667 & 1150.02 \\
\hline 8 & MC WAX & 95.5 & 1.111 & 106.10 & 1.111 & 106.10 & 1.111 & 106.10 & 1.111 & 106.10 \\
\hline 9 & HS/ LG (TMQ) & 198.54 & 0.556 & 110.39 & 0.556 & 110.39 & 0.556 & 110.39 & 0.556 & 110.39 \\
\hline 10 & PEG \#4000 & 128 & 0.375 & 48.00 & 0.375 & 48.00 & 0.375 & 48.00 & 0.375 & 48.00 \\
\hline 11 & CARBON BLACK (N 220) & 86.73 & 8.330 & 722.46 & 20.000 & 1734.60 & 20.000 & 1734.60 & 20.000 & 1734.60 \\
\hline 12 & EVA Crump & 8.5 & 0.000 & 0.00 & 0.000 & 0.00 & 35.000 & 297.50 & 0.000 & 0.00 \\
\hline 13 & Napthenic Oil & 100 & 0.000 & 0.00 & 0.000 & 0.00 & 0.000 & 0.00 & 8.000 & 800.00 \\
\hline 14 & Aroma (Perfume) & 400 & 0.000 & 0.00 & 0.000 & 0.00 & 0.000 & 0.00 & 7.980 & 3192.00 \\
\hline MASTER BATCH WT. (Kg)/ Cost & & 174.54 & 29656.51 & 182.321 & 30450.86 & 217.32 & 30748.36 & 198.30 & 34442.86 \\
\hline & & MB & 169.91 & MB & 167.02 & MB & 141.49 & MB & 173.69 \\
\hline
\end{tabular}




\begin{tabular}{|c|c|c|c|c|c|c|c|c|c|c|}
\hline & & & $\mathrm{Kg}$ & & $\mathrm{Kg}$ & & $\mathrm{Kg}$ & & $\mathrm{Kg}$ & \\
\hline 15 & MBT & 209.57 & 0.500 & 104.79 & 0.500 & 104.79 & 0.500 & 104.79 & 0.500 & 104.79 \\
\hline 16 & MBTS & 231.63 & 1.278 & 296.02 & 1.278 & 296.02 & 1.278 & 296.02 & 1.278 & 296.02 \\
\hline 17 & TMTD & 154.42 & 0.139 & 21.46 & 0.139 & 21.46 & 0.139 & 21.46 & 0.139 & 21.46 \\
\hline 18 & SULPHUR & 20 & 2.333 & 46.66 & 2.333 & 46.66 & 2.333 & 46.66 & 2.333 & 46.66 \\
\hline 19 & Vulcanit-G(PVI)(FB) & 336.42 & 0.083 & 27.92 & 0.083 & 27.92 & 0.083 & 27.92 & 0.083 & 27.92 \\
\hline \multicolumn{2}{|c|}{ CURING AGENT WT. $(\mathrm{Kg})$} & & 4.333 & 496.855 & 4.333 & 496.86 & 4.333 & 496.86 & 4.333 & 496.86 \\
\hline \multicolumn{2}{|r|}{ TOTAL WT. $(\mathrm{Kg})$} & & 178.873 & 30153.37 & 186.654 & 30947.72 & 221.654 & 31245.22 & 202.634 & 34939.72 \\
\hline & & & $\begin{array}{c}\text { FB } \\
\text { Cost / } \\
\mathrm{Kg}\end{array}$ & 168.57 & $\begin{array}{c}\text { FB } \\
\text { Cost / } \\
\text { Kg }\end{array}$ & 165.80 & $\begin{array}{c}\text { MB } \\
\text { Cost / } \\
\mathrm{Kg}\end{array}$ & 140.96 & $\begin{array}{c}\text { FB } \\
\text { Cost / } \\
\text { Kg }\end{array}$ & 172.43 \\
\hline
\end{tabular}

In continuation

\begin{tabular}{|c|c|c|c|c|c|c|c|c|c|}
\hline R \& D No. 02 & Cost & R \& D No. 03 & Cost & R \& D No. 04 & Cost & R \& D No. 05 & Cost & R \& D No. 06 & Cost \\
\hline 50.000 & 11100.00 & 50.000 & 11100.00 & 50.000 & 11100.00 & 50.000 & 11100.00 & 50.000 & 11100.00 \\
\hline 38.889 & 10733.36 & 38.889 & 10733.36 & 38.889 & 10733.36 & 38.889 & 10733.36 & 38.889 & 10733.36 \\
\hline 11.111 & 2655.53 & 11.111 & 2655.53 & 11.111 & 2655.53 & 11.111 & 2655.53 & 11.111 & 2655.53 \\
\hline 5.556 & 638.94 & 5.556 & 638.94 & 5.556 & 638.94 & 5.556 & 638.94 & 5.556 & 638.94 \\
\hline 3.056 & 213.92 & 3.056 & 213.92 & 3.056 & 213.92 & 3.056 & 213.92 & 3.056 & 213.92 \\
\hline 35.000 & 1960.00 & 35.000 & 1960.00 & 35.000 & 1960.00 & 35.000 & 1960.00 & 35.000 & 1960.00 \\
\hline 8.333 & 574.98 & 8.333 & 574.98 & 8.333 & 574.98 & 12.083 & 833.73 & 0 & 0.00 \\
\hline 1.111 & 106.10 & 1.111 & 106.10 & 1.111 & 106.10 & 1.111 & 106.10 & 1.111 & 106.10 \\
\hline 0.556 & 110.39 & 0.556 & 110.39 & 0.556 & 110.39 & 0.556 & 110.39 & 0.556 & 110.39 \\
\hline 0.375 & 48.00 & 0.375 & 48.00 & 0.375 & 48.00 & 0.375 & 48.00 & 0.375 & 48.00 \\
\hline 20.000 & 1734.60 & 20.000 & 1734.60 & 20.000 & 1734.60 & 20.000 & 1734.60 & 20.000 & 1734.60 \\
\hline 0.000 & 0.00 & 0.000 & 0.00 & 35.000 & 297.50 & 35.000 & 297.50 & 35.000 & 297.50 \\
\hline 8.000 & 800.00 & 5.000 & 500.00 & 5.000 & 500.00 & 1.250 & 125.00 & 10.000 & 1000.00 \\
\hline 0.300 & 120.00 & 0.300 & 120.00 & 0.300 & 120.00 & 0.150 & 60.00 & 0.150 & 60.00 \\
\hline 182.287 & 30795.82 & 179.287 & 30495.819 & 214.29 & 30793.32 & 214.137 & 30617.07 & 210.804 & 30658.34 \\
\hline MB Cost / Kg & 168.94 & $\mathrm{MB}$ Cost / Kg & 170.09 & MB Cost / Kg & 143.70 & MB Cost / Kg & 142.98 & $\mathrm{MB}$ Cost / Kg & 145.44 \\
\hline 0.500 & 104.79 & 0.500 & 104.79 & 0.500 & 104.79 & 0.500 & 104.79 & 0.500 & 104.79 \\
\hline 1.278 & 296.02 & 1.278 & 296.02 & 1.278 & 296.02 & 1.278 & 296.02 & 1.278 & 296.02 \\
\hline 0.139 & 21.46 & 0.139 & 21.46 & 0.139 & 21.46 & 0.139 & 21.46 & 0.139 & 21.46 \\
\hline 2.333 & 46.66 & 2.333 & 46.66 & 2.333 & 46.66 & 2.333 & 46.66 & 2.333 & 46.66 \\
\hline 0.083 & 27.92 & 0.083 & 27.92 & 0.083 & 27.92 & 0.083 & 27.92 & 0.083 & 27.92 \\
\hline 4.333 & 496.86 & 4.333 & 496.86 & 4.333 & 496.86 & 4.333 & 496.86 & 4.333 & 496.855 \\
\hline 186.62 & 31292.67 & 183.620 & 30992.67 & 218.62 & 31290.17 & 218.47 & 31113.92 & 215.14 & 31155.20 \\
\hline FB Cost / Kg & 167.68 & $\mathrm{FB}$ Cost / Kg & 168.79 & FB Cost / Kg & 143.13 & FB Cost / Kg & 142.42 & $\mathrm{FB}$ Cost / Kg & 144.82 \\
\hline
\end{tabular}

Highly dispersed silica (silicon dioxide) having a specified surface area in the range of about 5 to about 1,000 , preferably about 20 to about $300 \mathrm{~m}^{2} / \mathrm{g}$ (determined with gaseous nitrogen according to the known BET procedure) and with primary particle sizes in the range of about 5 to about $500 \mathrm{~nm}$ (nano meter, $10^{-9}$ meters) which can be produced, for example, by precipitation from solution of silicates by hydrolysis and/or oxidative high temperature conversion. There can also be used flame hydrolysis of volatile silicon halides, e.g., silicon tetrachloride or electric arc processes. These silicas, in a given case, can also be present as mixed oxides or oxide mixtures with oxides of the metals aluminium (alumina), magnesium(magnesium oxide), calcium (calcium oxide), barium (barium oxide), zinc (zinc oxide), zirconium (e.g., zirconium dioxide) or titanium (e.g., titanium dioxide). ${ }^{26-29}$

\section{Conclusions}

The use of EVA crumps in the formulations of rubber soles brought the cost of manufacturing quite feasible. The use of $\mathrm{ZnO}$ proven to be very good cross linker and the process of vulcanization was technically successful. The properties of rubber soles were found to be altered specifically softness of the soles. Nevertheless with employing $0.150 \mathrm{Kg}$ of aroma found to have the masking of the rubber odour and the properties of the soles were as per specification. EVA provided the flexibility to the rubber soles. Employing the use of stearic acid in the formulations exhibited very good lubrication. The work now has successfully become the routine production of the company.

\section{ACKNOWLEDGEMENTS}

I am thankful to my technical team and quality control team for their untiring support in evaluating all the physical evaluations. FDDI also deserves a special thank for analysing the standard physical evaluations. 


\section{REFERENCES}

[1] Hayashi, H. (Nonaka, Kurume, Fukuoka, JA) Ishii, S. (Tsubukuhon, Kurume, Fukuoka, JA) Injection molding machine for the manufacture of shoes, US Patent 4068995, 1976

[2] Raymond, L. N. Zinc oxide coated particles, compositions containing the same, and methods for making the same US patent 76357292008

[3] Masatoshi, C. Masatada, F. Takashi, T. Naoaki, S. Yoshihisa, S. Nanami, M. Katsuyiki T. Kohei M. zinc oxide coated particles, compositions containing the same, and methods for making the same, Japan Patent Office, Publ. No. JP .

[4] Howard, G. Andrew, R. Clay mineral products and their use in a rubber compositions U.S. Patent 2004/0249045 A1 2004

[5] Raymond, L.N. Zinc oxide coated particles, compositions containing the same, and methods for making the same U.S. Patent 76357292007

[6] Nip, R. L., Zinc oxide coated particles, compositions containing the same, and methods for making the same US patent 115199492006

[7] Kraus-Degree of Cure in Filler-Reinforced Vulcanizates, I and II, Rubber World, Oct. /Nov. pp. 67-73 and 254-259 1956

[8] Antar; M. (New York, NY) Nunes; V. M., (Cumberland, RI) Orthopedic cast walker boot US patent 58272101996

[9] Ronald J. R., (Newtown, PA, US) Fragrance releasing scented shoes and shoe soles, US patent 200802713472008

[10] Winspear, G. G., ed. The Vanderbilt Latex Handbook. Norwalk, CT: R.T.Vanderbilt Company, Inc., 1954.

[11] Mausser, R. F., ed. The Vanderbilt Latex Handbook. Norwalk, CT: R.T.Vanderbilt Company, Inc., 1987.

[12] Carl, J. C. Neoprene Latex. Wilmington, DE: E. I. Du Pont de Nemours \&Co, Inc., 1962.

[13] Noble, R. J. PhD., Latex in Industry. Bristol, CT: Palmerton Publishing Company, Inc., 1953.

[14] Skeist, I. PhD. Handbook of Adhesives, Third Edition. New York: Van No strand Reinhold, 1990.
[15] Pendle, T. D. "Methylmethacrylate Graft Polymer Latexes," in The Vanderbilt Latex Handbook, ed. Robert F. Mausser (Norwalk, CT: R.T. Vanderbilt Company, 1987), p. 17.

[16] Royce, J. N. Latex in Industry (Bristol, CT: Palmerton Publishing Company,Inc., 1953) p. 229

[17] John, C. C. Neoprene Latex (Wilmington, DE: E.I. duPont deNemours \& Co.,Inc., 1962) p. 10

[18] Pole, E. G. "Carboxylated Styrene-Butadiene Latex," in The Vanderbilt Latex Handbook, ed. Robert F. Mausser (Norwalk, CT: R. T. Vanderbilt Company, 1987), p. 31

[19] Christopher, N. Peroxide Curing of Rubber, R. T. Vanderbilt Co., Inc. 2003.

[20] Anne Z. Casey, "Water Based, Pressure Sensitive Adhesives," in The Vanderbilt Latex Handbook, ed. Robert F. M. (Norwalk CT: R.T.Vanderbilt Company, Inc, 1987), pp. 233 to 243.

[21] Thomas, S. S., "Bonding Textiles to Rubber," in Handbook of Adhesives, Third Edition, ed. Irving Skeist (New York: Van Nostrand Reinhold, 1990), pp 59719

[22] Christopher N., Robert D., International Latex Conference, Akron, Surface Morphology of Prevulcanized Natural Rubber Latex Films by Atomic

[23] Force Microscopy: New Insight into the Prevulcanization Mechanism, OH, July 27, 1999.

[24] Ho C.C. Khew, M.C. Langmuir 15 (19) 6208-6219, 1999.

[25] Ichikawa, M. Hamada, European Patent Application, EP 1149902A1, 2001

[26] Perrella, P., Tillotson, United States Patent, US 6,380,283 B1, 2002

[27] Tanaka, N., Ochi, S., Hayashi, S. K. Kanamaru United States Patent, 5,910,567, 1999

[28] Pugh, Culp, United States Patent, 5, 780, 112, 1998

[29] Christopher N., Peroxide Curing of Rubber, R. T. Vanderbilt Co., Inc. 2003.

[30] W. McGlothlin, International Latex Conference, Akron, OH, August 1, 2001. 